\title{
SANITARY LANDFILL COSTS FROM DESIGN TO AFTERCARE: CRITERIA FOR DEFINING UNIT COST
}

\author{
Alberto Pivato ${ }^{1, *}$, Salvatore Masi ${ }^{2}$, Diego De Caprio ${ }^{3}$ and Anna Tommasin ${ }^{1}$ \\ ${ }^{1}$ ICEA, Department of Civil, Environmental and Architectural Engineering, University of Padova, via Marzolo 9, 35131 Padova, Italy \\ ${ }_{2}^{2}$ University of Basilicata, School of Engineering, viale dell'Ateneo Lucano, 10, Potenza, Italy \\ ${ }^{3}$ Regione del Veneto, Area Tutela e sviluppo del territorio Direzione Ambiente - Unità Organizzativa Ciclo dei rifiuti, Palazzo Linetti, \\ Calle Priuli, 99, 30121 Venezia, Italy
}
Article Info:
Received:
17 January 2018
Revised:
26 November 2018
Accepted:
5 December 2018
Available online:
21 December 2018
Keywords:
Cost analysis
Design costs
Construction costs
Operation costs
Aftercare costs
Landfill gate fee

\begin{abstract}
Landfill costs have been estimated for an average case that represents a reference landfill model for Northern Italy. This case is based on the analysis of more than 15 landfill projects per the requirements of the Italian legislation. These projects were based on the suggestions of the national landfill guidelines and best practices. Costs have been analysed through the four phases of the landfill lifetime (i.e.: design and authorization, construction, operation, and aftercare) and expressed per unit of waste volume in order to define the "landfill gate fee" that represents a unit payment for the whole landfill life cycle service. The estimated value, equal to $86.04 € / \mathrm{m}^{3}$, is in line with the analysed references and it is mainly attributed to the costs of leachate disposal, the staff, and raw materials for liner construction. However, other factors such as localization, climatic conditions, waste quality, landfill geometry, operative procedures, and financial and legal aspects can significantly influence the landfill gate fee. Finally, the results of this study, based on a large data analysis, represent a starting point for a comparative economic analysis to support political and technical decisions.
\end{abstract}

\section{INTRODUCTION}

Italian (art. 179 of D. Lgs. 152/2006) and European norms (art. 4 of Directive 98/CE/2008) that regulate the prevention and management of waste considers sanitary landfills at the bottom of the hierarchy which includes the following strategies: prevention, preparation for re-use, recycling, other recovery (e.g.: energy recovery), and disposal. In this regulatory framework, sanitary landfills in Italy can only accept pre-treated waste with the exception of few specific cases (art. 7 of D.Lgs 36/2003 and ISPRA, 2016).

However, sanitary landfills can properly meet waste management objectives while ensuring higher safety standards and operating flexibility compared to other final waste destinations. In fact, a landfill can operate within a wide range of potentiality (tons of waste per year) without requiring substantial structural changes and without significantly increasing emissions.

The sanitary landfill technology responds better than any other system to waste composition variability and it can be used, without any particular problems, to dispose of waste fluxes with different chemical compositions.

These characteristics make the landfill an indispens- able component of integrated waste management systems that need to meet the following requirements:

- High fluctuations and seasonal peaks of waste streams production, as is the case of tourist areas or exceptional/occasional waste disposals;

- High temporal variability (e.g.: ten years) of the disposal requirement;

- Heterogeneous waste fractions from different waste recovery and stabilization treatments.

The sanitary landfill still represents a reliable technology in areas where waste production is very low and/or where significant distances discourage waste transportation to local facilities. It can represent the only solution for developing countries who find it difficult to implement more complex and often more expensive plants.

However, we have to not think that a landfill is a low technology that is easy to manage and does not require complex engineering components and high-technology materials.

Landfills can ensure that safety standards are implemented that are equal or higher than other waste management technologies at lower costs. Costs thus becomes the 
"independent variable" whose value is used to select the best option.

An appropriate estimation of landfill costs needs to consider the following key elements:

- Site factors: permeability of the soil; geotechnical stability of the walls (angle of natural stability); morphology and presence of excavations (quarries); presence of roads; presence of network services in the area (power lines, drainage system, etc.);

- Climatic and environmental factors: rainfall intensity (average value and seasonal variability of precipitation); temperatures and potential evaporation; intensity and persistence of winds; exceptional presence of birds and other animals; etc;

- Overall geometry and dimensions of the landfill: area and height of landfills; daily quantity of disposed waste; weekly or seasonal peaks in disposal; planned stops of plant operations;

- Presence of other management utilities: waste water treatment plant; biogas recovery units; etc;

- Operational activities: the rate at which the landfill is filled; costs for daily cover/restoration; etc;

- Financial aspects due to investments and taxes (landfill tax and contribution for landfill environmental annoyance);

- Land acquisition.

In addition to the above factors, regulatory technical requirements (minimum thickness of the clay layer, type of the geomembrane, the composition of the top cover, etc.) contribute significantly to the formation of landfill costs.

The main aim of this study is to define the landfill "gate fee" (typically per tonne) for the whole life cycle service. This analysis can be useful for many purposes such as:

- Defining the disposal costs for official price lists;

- Planning the best waste management system;

- Evaluating the economic impact of innovative technical interventions: energy crops application on top cover (Garbo et al., 2017; Lavagnolo et al., 2016); leachate recirculation; in-situ aeration application (Raga et al., 2015); new environmental compensation or mitigation applications (Pivato et al., 2013; Kunreuther and Easterling, 1996); etc;

- Improving the knowledge of the entire life cycle cost of a consumer good (from procurement of raw materials to disposal);

- Analysing the impact of the reduction of specific taxes or financial guarantees when innovative interventions are applied to the landfill to reduce long term emissions;

- Comparing the cost of the different landfill phases (construction, operation and aftercare) and their optimizations through the application of design alternatives.

\section{MATERIAL AND METHODS}

Costs along the landfill lifetime depend on several factors, strictly correlated to the design of the landfill itself. In this view, key points regarding the landfill type (for inert, non-hazardous or hazardous waste, according to the EU and Italian laws Council Directive 99/31/EC and D.Lgs. $36 / 2003$, respectively) and the quantity and quality of the disposed waste (e.g.: moisture content, biodegradable fraction). Their influence on costs is significant, since they affect the constructive aspects (e.g.: total landfill height, planned landfill lifetime), management aspects (e.g.: use of pre-treatments, waste compaction, in-situ leachate treatment), required capital investment (e.g.: area acquisition, machinery, devices, materials, energy), labor force employed (e.g.: number of staff workers and managers), financial expenses, insurance policies, and taxes. Site planning is also fundamental in the cost definition. For instance, the construction costs for a landfill in a mountain area will be much higher compared to an equivalent one built on plain land, or, in some cases, in hill land, without significant physical constrains.

The definition of a "representative" landfill case becomes a key issue in order to generalize the results as much as possible and, therefore, to avoid the analysis of a specific landfill, which could result too much restriction for comparison and too much site dependency.

In this study, cost estimations are referred to as an average case that represents a reference model landfill for the Northern-Italy region. These estimates are based on the analysis of more than 15 landfill projects per the requirements of current legislation (D.Lgs. 36/2003) as well as suggestions of national landfills guidelines (CTD, 1997; DGR n. X/2461/2014) and on best practices.

Landfill cost and benefit analyses were performed throughout the four phases of the landfill lifetime (design and authorization, construction, operation, and aftercare) using reference unit prices from official price lists and market surveys.

Finally, all costs were grouped into economic or functional categories and correlated to the available waste volume of the landfill, which were assumed as a reference unit. In this view, it is important to note that landfill cost analysis usually refers to the total price ratio to the weight of waste disposed and not to the volume. The reasons behind this choice are explained in the following paragraphs. Figure 1 shows the methodology adopted in this work.

\subsection{Model landfill definition}

The statistical analysis of several case studies, mainly from the Veneto and Lombardia regions, were used to develop the definition of the geometry (volume and surface) and the most important landfill constructive and operational characteristics.

The model landfill is defined as a non-hazardous waste and underground landfill developed in a pre-existing excavation of an exhausted borrow pit (as $60 \%$ of the investigated landfills are underground); therefore, construction and management characteristics rely on these basic assumptions.

The total landfill volume after settlement is about $1,000,000 \mathrm{~m}^{3}$, which corresponds approximately to a height of $27 \mathrm{~m}$ ( $17 \mathrm{~m}$ underground, $7 \mathrm{~m}$ above the ground level and almost $3 \mathrm{~m}$ considering both temporary and final top covers) and a landfill surface of $50,000 \mathrm{~m}^{2}$ at the ground level. The volume related only to waste is about 800,000 
$\mathrm{m}^{3}$, and therefore daily, temporary, and final top covers are not included in this value. Four hydraulically independent sectors are considered and the bottom liner and top cover are defined in accordance with D.Lgs 36/2003 and Lombardia regional landfill guidelines (DGR n. X/2461/2014). The fixed operation time is 10 years and the aftercare period is 30 years.

The dimensions of the devices needed for leachate, landfill gas (LFG), and rainwater management rely on calculations obtained by the implementation of specific models. In particular, for leachate production estimation, a hydrological balance model was performed (Canziani et al., 1989):

- $L=P-E$, for the operational phase;

- $L=P-R-E T$, for the aftercare phase.

Where: $L$ is leachate production, $P$ is precipitation, $E$ is evaporation, $\mathrm{R}$ is runoff and $\mathrm{ET}$ is evapotranspiration. The terms are estimated by the implementation of appropriate models.

Precipitation is estimated by taking the monthly average data (10 years monitoring) provided by the Villafranca (VR) weather station located approximately in the center of the area covered by the statistic.

The evaporation term relies on the application of the Turk formula and the evapotranspiration on the Thorntwaite formula (Canziani et al., 1989). The runoff refers to the work of Blakey (1992).

The most important results obtained from the application of this model are:

- Maximum yearly leachate production: 5,549 $\mathrm{m}^{3} /$ year in operational phase;

- Yearly leachate production in aftercare: constant and equal to $2,027 \mathrm{~m}^{3} /$ year;

- Cumulative leachate production: $42,540.31 \mathrm{~m}^{3}$ in operational phase and $60,826.15 \mathrm{~m}^{3}$ in aftercare, on a total of $103,366.46 \mathrm{~m}^{3}$ in 40 years (see Figure 2).

Leachate collection is performed by a leachate drainage system, made of a drainage gravel layer on the bottom

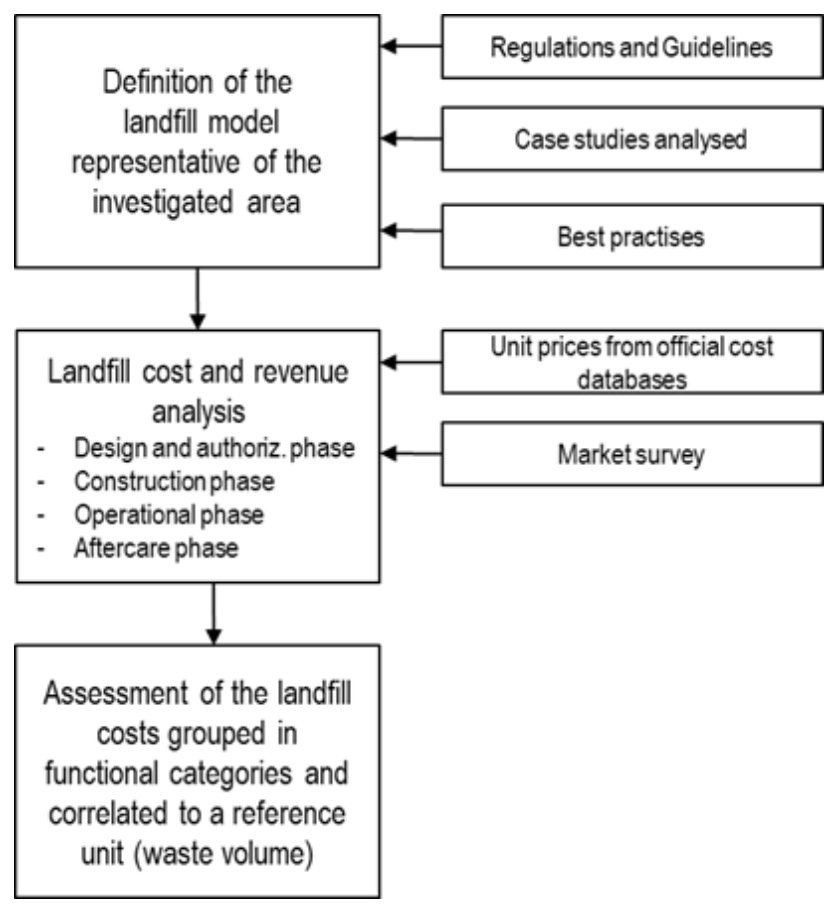

FIGURE 1: General scheme of implemented procedures.

liner and slotted pipelines. The pipelines are arranged in four sectors and it consisted of a primary pipe and secondary pipes. The latter organized in a herringbone pattern. The pipelines slope is assumed to be $2 \%$. The leachate is then collected from the South side of the landfill and delivered, through submersible pumps, to the leachate collection pipe (the removal pipe) and finally to the leachate storage system. The leachate is stored in three $100 \mathrm{~m}^{3}$ fiberglass tanks. An extra tank with the same dimensions is assumed as a reserve. The tanks are placed on a concrete-made containment basin of $420 \mathrm{~m}^{3}$ (internal length of $21 \mathrm{~m}$, internal width of $8 \mathrm{~m}$, and internal height of 2.5 $\mathrm{m})$. The containment basin represents a safety measure in case of a failure in the fiberglass storage tanks. Leachate tanks are emptied periodically, on a schedule defined in

\section{Cumulative leachate production}

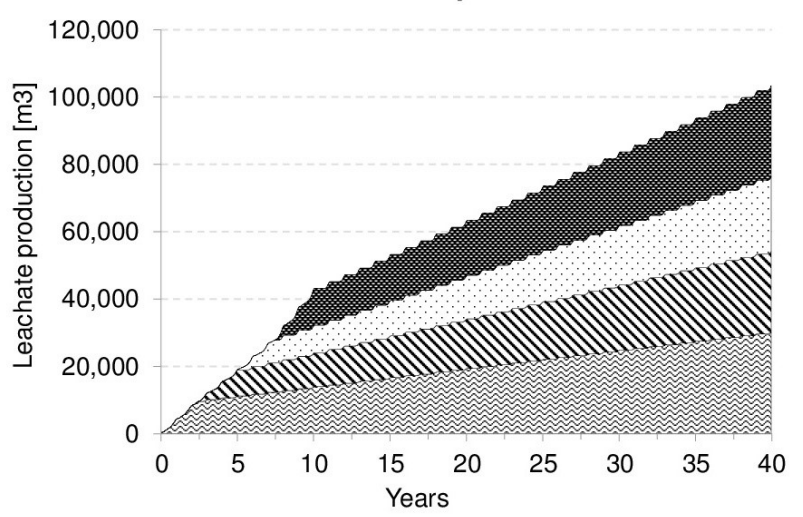

\section{Cumulative LFG production}

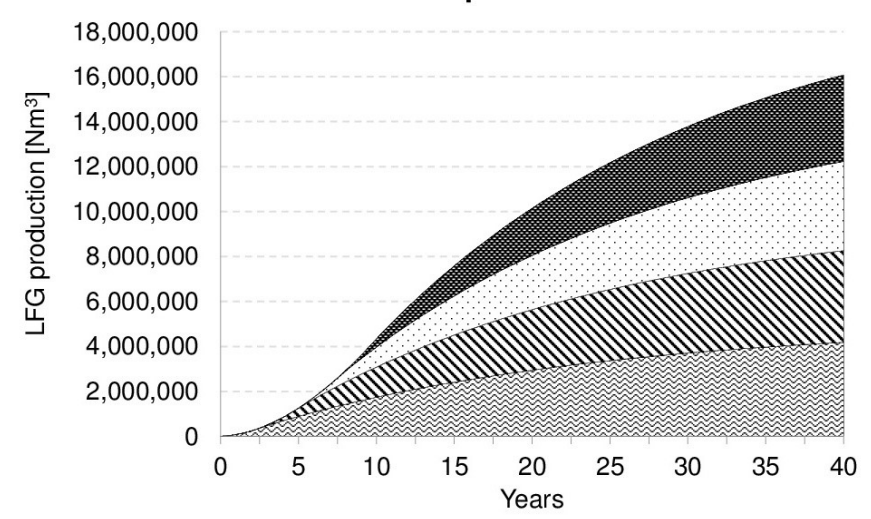

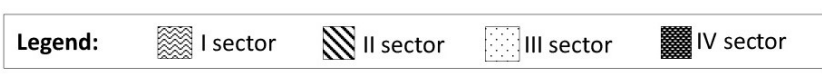

FIGURE 2: Cumulative leachate and LFG production over 40 years (10 years of operational phase and 30 years of aftercare phase). 
accordance with the specific leachate production period. The leachate is then sent to an external treatment plant. No in-situ leachate treatment is assumed.

The estimation of LFG production is based on the work of Cossu et al. (1992). The methane content in the LFG was assumed as $50 \%$ and the LFG collection efficiency was assumed to be $70 \%$ of the total produced (DGRV $n$. 995/2000). The estimated values are reported in Figure 2 and summarized as follow:

- Maximum yearly LFG production: 743,034 $\mathrm{Nm}^{3} /$ year occurring in the 11th year;

- Cumulative LFG production: $3,955,642 \mathrm{Nm}^{3}$ in the operational phase and $12,025,537 \mathrm{Nm}^{3}$ in aftercare, for a total of $15,981,180 \mathrm{Nm}^{3}$ over 40 years.

The LFG collection system consists of 42 vertical wells (external diameter $600 \mathrm{~mm}$, internal slotted pipe $160 \mathrm{~mm}$ ) installed in the landfill. Each well has a specific maximum influence radius according to its location: $20 \mathrm{~m}$ near the border and $35 \mathrm{~m}$ in the center of the landfill. Wells are linked to four regulation stations, which are connected to the extraction station. Because of the low quantity of LFG produced, energy recover is not worthwhile (DGRV $n$. $995 / 2000)$. A flare is included and is designed in accordance with D.Lgs. 36/03 and CTD (1997).

The landfill was built in an area of about $94,500 \mathrm{~m}^{2}$ which includes the auxiliary buildings and services needed for its proper operation and management. These buildings and services include: leachate storage system, LFG extraction station and flare, internal roads, and service area. The service area $\left(3,950 \mathrm{~m}^{2}\right)$ includes temporary storage, an office building, car and truck parking areas, a tire washing system, and a platform scale. The dimensions of these areas are defined through specific calculations, which considers possible law restrictions and other similar designs solutions.

The service area rainwater drainage system was designed using a climatic curve for a return period of 50 years. The first rain falling in the service area, represented by the first $5 \mathrm{~mm}$ of precipitation, is collected and treated in the first rainwater treatment system. The treated water is then stored in an underground water storage tank with a volume of $31.5 \mathrm{~m}^{3}$. This water storage tank also receives rainwater from the service building roof. The stored water is reserved for the tire washing system and other uses, including the fire prevention system. The excess rainwater is released into a rainwater drainage trench located close to the first rainwater treatment system. This service area drainage trench is $18 \mathrm{~m}$ long and it has a trapezoidal shape (larger base $3 \mathrm{~m}$, shorter base $2 \mathrm{~m}$ and height $2 \mathrm{~m}$ ). The wastewater from the service building is treated with a grease separator and an Imhoff tank. The residual wastewater flow is then sent to a phytodepuration system with a surface area of $20 \mathrm{~m}^{2}$ that was obtained by assuming 4 p.e. (population equivalent) and $5 \mathrm{~m}^{2} /$ p.e (ISPRA, 2012).

Rain falling on the landfill top cover is collected by a perimeter channel (trapezoidal shape, larger base $1.5 \mathrm{~m}$, shorter base $0.5 \mathrm{~m}$, height $0.5 \mathrm{~m}$ ). In this case, according to D.Lgs $36 / 2003$, this design relies on a climatic curve for a return period of 10 years. Rainwater collected is then released into another drainage trench, with the dimensions of the service area drainage trench except with a different length. This trench is $110 \mathrm{~m}$ long and located along the East side of the landfill.

Eight people are assumed to work at the landfill during the operational phase: an operations director, a technician responsible for the plant, two technical-administrative employees, three workmen, and a supervisor.

Figure 3 shows the landfill model as projected with the the aforementioned services, the leachate and LFG collection system configuration, and the defined liner system.

The characterization of the disposed waste was assumed as follows (percentages are expressed on wet weight base): paper $1.5 \%$, cardboard $1.5 \%$, glass and inert $52 \%$, plastic $12 \%$, metals $3 \%$, stabilized inert $15 \%$, and sludge $15 \%$. These values refer to the residual and pre-treated fractions and are consistent with those assumed in the investigated cases. However, when designing a landfill, the waste characterization is not a simple straightforward definition and sometimes it is estimated without any further lab investigations. It is also difficult to know the temporal and spatial dynamics related to the quality and quantity of the incoming waste. For example, the European Union's Directives are working to limit landfilling and avoiding any recyclable material being landfilled. Consequently, it is expected that the amount of recyclables will decrease in future landfills which could increase the expected life of the landfill but also could modify the assumptions made regarding the waste composition entering the landfill.

Today, most of the waste received by non-hazardous waste landfills is represented by special waste produced by economic activities due to the difficulty to fill landfills only with MSW.

In Italy, the analysis of non-hazardous special waste production data (Laraia, 2017) by economic activity highlights that the construction and demolition industries represent the highest percentage $(42.3 \%)$. Waste treatment and recovery activities follow (27.2\%) along with manufacturing (19.2\%), which include the quantities resulting from mechanical biological treatment of MSW. All of the remaining activities (e.g.: services, trade, transport; administrative, education and health services; agriculture, forestry, hunting and fishing; mining and quarrying; electricity, gas, steam and air; water supply; sewerage) accounted for $11.3 \%$ of the overall production of non- hazardous waste.

Sector experts estimate that in these landfills MSW does not exceed $30 \%$ of the total waste disposed. According to this assumption, the classification of waste disposed in the landfill model is 30\% MSW and 70\% Special Waste. It is also assumed that the waste characterization already takes into account this waste type ratio.

In the waste characterization assumed, unsorted and putrescible waste are not included as waste fractions categories. However, biodegradability is considered in the other fractions: paper and cardboard are considered slowly biodegradable and the sludge fraction is considered highly biodegradable. The choice not to define a separate category for putrescible material, comes from the landfill disposal trends over the last years. As a matter of fact, over the last 

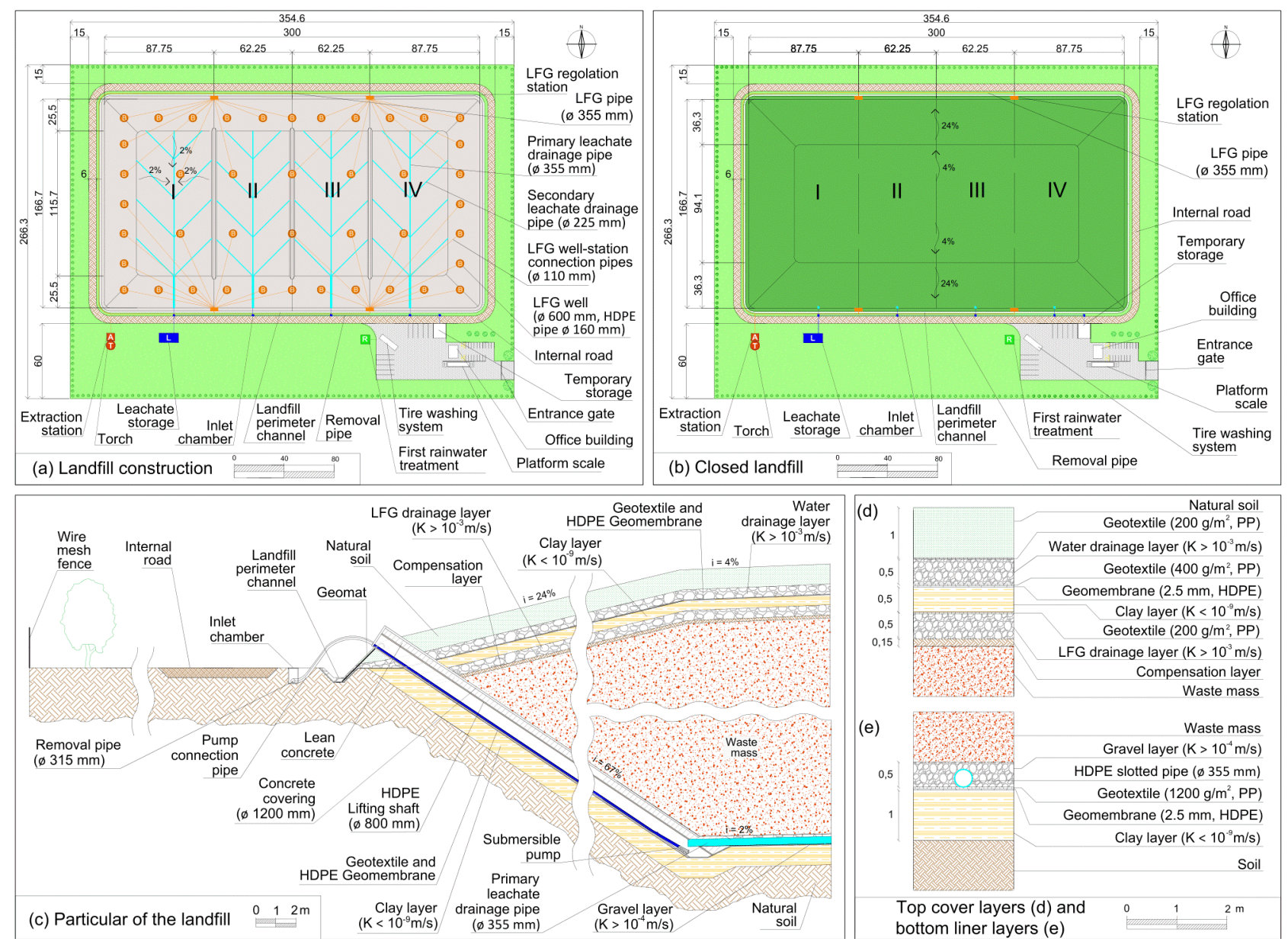

FIGURE 3: Detailed landfill model schematic

15 years the increased restrictive legislation targets caused a significant reduction in the biodegradable fractions disposed of in landfills. In Italy, the greatest reduction of $78 \%$ was achieved in the Veneto Region (DGRV n. 1245/2016). The biodegradable fraction disposed into the landfill, calculated as kilograms of biodegradable waste per inhabitant per year, decreased from the value of $133 \mathrm{~kg} / \mathrm{year} / \mathrm{inh}$ habitant in 2002 to $29 \mathrm{~kg} /$ year/inhabitant in 2014 (Annex A, DGRV n. 1245/2016). It is important to remember that, these data only refers to the MSW portion of the waste disposed. Therefore, in the case of non-hazardous waste landfills the real value of biodegradable waste disposed may be higher, since it also includes the fraction from special waste.

Waste characterization is also strictly connected with waste density and indirectly to the degree of utilization of the landfill. Waste density could be calculated considering single waste fraction densities however this would be an oversimplification of reality because its value is reflective of site specific conditions and dependent on time and the processes occurring during the landfill lifetime. In the present study, in order to follow the goal of generalization of the landfill model, a waste density of $1.1 \mathrm{t} / \mathrm{m}^{3}$ is assumed. This value aligns well with the other case studios considered. Hence, considering the total volume of the waste disposed, the waste inflow calculated is $88,000 \mathrm{t} /$ year.

\subsection{Sanitary landfill life cycle}

The landfill costs must consider all the landfill life phases:

- Design and authorization phase (1-3 years): waste characterization study, projects, construction management, testing and security coordination, meetings;

- Construction phase (1-2 years): site operation (excavation, backfilling of soil, etc), construction of the main parts of landfill body (barrier layer, leachate and LFG collection) and construction of other facilities at the landfill site (such as monitoring system, internal road and office building);

- Operational phase (10 years): operation of the landfill, for example the transport of waste from the outside, the placement and compaction of waste, the daily coverage, the environmental monitoring (groundwater, surface water and air around the plant), and leachate and LFG management;

- Aftercare phase (30 years): operations planned for this phase consist of monitoring and maintenance activities, which are mainly: top cover maintenance and monitoring, leachate collection system operation and maintenance, LFG collection system maintenance and monitoring, LFG migration control and monitoring, groundwater and surface water monitoring, security and ground stability maintenance. 
A proper estimate of the duration of each phase is fundamental and is importance especially from an economic point of view. In fact, costs of each phase should be referenced and homogenized to a specific time frame (temporal homogenization of the costs). Further considerations of this particular subject are discussed in the following section.

\subsection{Criteria for economic analysis}

The economic analysis for the determination of the landfill gate fee is based on the technical procedures used in the bill of quantities and in the financial plans.

Regarding the bill of quantities, a generic item of cost/ profit is determined applying the following expression:

Item cost $[€]=$ Quantity [reference unit] x Unit price $[€ /($ reference unit)]

The cost of this item refers to the cost of the specific intervention or operation considered (e.g. activity, equipment, material) and the reference unit of each item is selected each time following the most suitable unit of measure (e.g. $\mathrm{m}^{3}, \mathrm{~m}^{2}, \mathrm{~m}, \mathrm{t}$, body). In this work, quantities assumed are those defined above for the model landfill, whereas unit prices come from the official price lists of the Veneto (Veneto Region Price List, 2013) and Lombardia regions (Regione Lombardia, 2011) as well as from market analysis.

Regarding financial plans, interest rates for investments commonly applied in public projects were used.

Specific assumptions were applied for the following items:

\section{- Actualization of cost and revenue}

Cost and revenue of activities/works realized at different times should be actualized. However, in real cases assumptions are made to consider unit costs equal for all of the landfill lifetime. This is also the case for the present study.

\section{- Tender discounts}

Tender discounts for public contracts should be clarified. For those generally in question, average discounts for engineering services without work execution is $38.2 \%$ with peaks of $70 \%$; for engineering services with work execution the average is $16.3 \%$ with a peak of $50.6 \%$ (CNI, 2016).

Generally, these discounts don't depend on technical variables and are difficult to forecast. However, if they are applied, often the reduction in cost is compensated by other costs, such as unexpected events, design errors, or appraisals. In the work, these discounts were not considered.

\section{- Reference units}

Costs usually refer to the unit of weight of waste disposed. Reasons are mainly practical, since the quantity of waste disposed in a landfill is measured by weighing the trucks. However, referring to unit of volume better takes into account the waste volume which avoids the influence of waste quality and type.

For example, the landfill cost referred to as a unit of weight of glass swarf (specific weight greater than $1.6 \mathrm{t}$ / $\left.\mathrm{m}^{3}\right)$ is double relative to the cost referred to normal MSW ( $0.8 \mathrm{t} / \mathrm{m}^{3}$ after compaction), even if they occupy the same volume in the landfill; glass swarf however does not generate biogas or release pollutants in the leachate. In this sense, the cost correlated to weight results are restrictive.

Therefore, in accordance with the above considerations, the costs of the model landfill refers to the unit of volume. The volume considered as reference is the volume for waste equal to $800,000 \mathrm{~m}^{3}$.

The weight/volume reference issue is similar to the concept of degree of utilization of the landfill (or utilization factor of the volumes). It represents the ratio between the quantity of waste disposed and the volume. Therefore from a dimensional point of view, the unit of measure is $t /$ $\mathrm{m}^{3}$. This dimensional similarity to density must not be misleading, because the meaning is different. Several factors affect the degree of utilization of the landfill. Besides the specific landfill site characteristics and the quantity and quality of waste disposed, the most important are:

- Density: the increase in the waste density value allows taking full advantage of landfill volumes. Considering the same volumes, higher density values mean larger quantity of waste that can be dispose of;

- Waste pre-treatments: they can maximize the usable landfill volume. Compaction maximization became fundamental, especially for some materials for which it is difficult to reach large compaction levels (and then high values of density) after disposal in the landfill. This means that, for these materials, good compaction before disposal allows for some kind of landfill volume "recovery". This concept fits particularly well to the case of plastics, where the density can reach $0.9 \mathrm{t} / \mathrm{m}^{3}$ with a compactor roller, and it is around $0.4-0.5 \mathrm{t} / \mathrm{m}^{3}$ with simple mechanical shovel. In general, the compaction density has a physical limit, which cannot be exceeded even with stronger compaction. In case of the aforementioned plastic fraction, the maximum density values can reach close to $1 \mathrm{t} / \mathrm{m}^{3}$, while it is around $2.5 \mathrm{t} /$ $\mathrm{m}^{3}$ for glass swarf, $7.5 \mathrm{t} / \mathrm{m}^{3}$ for ferrous waste, $2-2.5 \mathrm{t} /$ $\mathrm{m}^{3}$ for stones inert, and $1.5-2 \mathrm{t} / \mathrm{m}^{3}$ for combustion residues;

- Settlements: this factor strongly influences the degree of utilization of the landfill volume. In this view, landfill closure timing is important, since settlement that occurs before the closure determines the possibility of disposing other waste within the volumes, that otherwise would be "lost" (if the landfill is closed, it is impossible to dispose other waste). The biodegradable fraction has a significant volume reduction potential since its tendency to lose water;

- Daily cover: it can significantly decrease the landfill volume available, since it can occupy a significant volume (5-10\% of the total landfill volume). Considering also that the other soil covers can occupy about $20 \%-33 \%$ of the total landfill volume (Ziyang et al., 2015). The daily cover, if made with layers of soil or biostabilized material, usually has thickness of $10 \mathrm{~cm}$ and is placed every one to two meters of disposed waste. Through rough calculations it means that for the landfill model, where 
the waste height is around $23 \mathrm{~m}$, the daily top cover has a total thickness of $1.2-2.3 \mathrm{~m}$. The corresponding volume for the daily cover layer must be subtracted from the usable landfill volume. Furthermore, this value can also increase, since settlement affects the waste layer thickness to greater extent than daily cover layers.

It is worth mentioning that in the case of slower disposal processes, the achievement of a minimum daily thickness of $1 \mathrm{~m}$ of waste needed for the placement of the daily cover can be difficult. For instance, with a waste inflow of $50 \mathrm{t} /$ day (density $1 \mathrm{ton} / \mathrm{m}^{3}$ ), a meter of waste thickness means the formation of an ideal solid with an area of 7 $\mathrm{m}$ by $7 \mathrm{~m}$ which is too small for compactor operations. Increasing that area to $10 \mathrm{~m}$ by $10 \mathrm{~m}$, the incidence of the daily cover on a height of $50 \mathrm{~cm}$ of waste becomes equal to about $20 \%$.

These considerations are important since they are a starting point for the optimization of the use of landfill volumes. However, these factors are really site specific and their influence on costs is difficult to evaluate.

\subsection{Sensitivity analysis}

The sensitivity analysis applied to the economic analysis is carried out using the "tornado" application of the program Crystal Ball@. The "tornado chart", a type of deterministic sensitivity analysis result output, was chosen to provide a graphical representation of the degree to which the results (in terms of unit cost in $€ / \mathrm{m}^{3}$ ) are sensitive to the specified Independent Variables (unit prices) with the other variables being held constant.

\section{LANDFILL COST AND REVENUE ANALYSIS}

The following sections detail the main analyses carried out to estimate the costs and revenues for the entire landfill life. The results are reported in Table 1 and are grouped into three levels of economic or functional categories: level one corresponds to the landfill phases plus an economic category (general expenses and net income) not correlated to a specific landfill phase but required at this level by specific national guidelines; level two corresponds to the main works/activities/services; level three corresponds to a more detailed description of the previous categories.

\subsection{Design and authorization phase}

The costs for design and authorization phases include the following technical activities: preliminary studies and surveys (topography, geology, geotechnical, etc.), waste characterization study, project management at different levels (preliminary, definitive and executive), plan for the operative and aftercare phases, security plan, site engineering, administrative and technical testing, and environmental impact assessment.

These aspects can be easily evaluated as a percentage of the construction cost ( $8 \%$ in this study). More sophisticated approaches such as the one suggested by Italian law DM 143/2013 use a parametric calculation based on three parameters: construction cost, performance complexity (buildings, structures, facilities, roads, etc.), and perfor- mance specificity (preliminary project, definitive project, executive project, etc.). However, these results are too high if compared to the ones from the selected statistic and they are not representative of applied costs.

Other costs for different authorization procedures such as investigation, notices, meeting, etc., can be estimated on the basis of worker hourly rates for the public sector.

\subsection{Construction phase}

The costs for the construction phase include the investment costs (area acquisition, construction cost, and machinery purchase) and the financial expenses due to investment and indirect costs.

Concerning construction cost, it is important to underline that some costs were included here even if not actually incurred during the construction period. This is necessary for an easier presentation of the results. This method was also followed in the majority of bill of quantities and financial plans analyzed. For example, in this case, we consider the temporary and final top covers, which are realized in the operational phase.

\subsubsection{Area acquisition}

Within a given country, as well as across countries, acquisition costs are difficult to specify in any formulaic manner. In some cases, the site may be acquired outright for a fee, in others, a royalty might be paid, or the site may be leased. It is difficult to generalize about the costs of acquisition and much depends upon the landowner in determining these costs.

In this work we adopted the methodology used for the compensation of a motorway called "Pedemontana Veneta" (2011) which reimburses voluntary transfer of non-building areas with a payment three times the Average Agricultural Value, assumed equal to $5 € / \mathrm{m}^{2}$. Therefore, area acquisition costs amounts $3 \times 5 € / \mathrm{m}^{2} \times 94,500 \mathrm{~m}^{2}=$ $€ 1,417,500$.

\subsubsection{Construction cost}

The construction cost includes all of the works planned by the project. It is important to underline that the costs are not considered in a chronological order, but they are grouped according to the type of work or area of interest.

Preliminary work include the construction and dismantling of the construction site and the excavation of general cleaning, while morphological shaping includes the cost for remodeling the borrow pit.

The costs of the bottom liner system and the top cover system arises due to the cost of supply and installation of the different liners required by regulations.

The cost related to the leachate system includes the slotted pipes for drainage, the lifting shafts for collection, the removal system, and the containment basin consisting of four storage tanks.

LFG system cost is due to the cost of wells and slotted pipes for the collection, connection pipes and regulation stations for the transport, and extraction station and flare for the disposal.

Monitoring includes the supply and installation of the piezometers for groundwater control, the weather station 
TABLE 1: Landfill gate fee calculation. The economic categories have been grouped in three levels: level one corresponds to the landfill phases plus the general expenses and net income; level two corresponds to the main works/activities/services; level three corresponds to a more detailed description of previous categories. The range of unit costs (where available) were estimated on the analysis of a statistic of more than 15 landfill projects designed on the basis of current legislation (D.Lgs. 36/2003), on the suggestions of national landfills guidelines (CTD, 1997; DGR n. X/2461/2014), and on best practices.

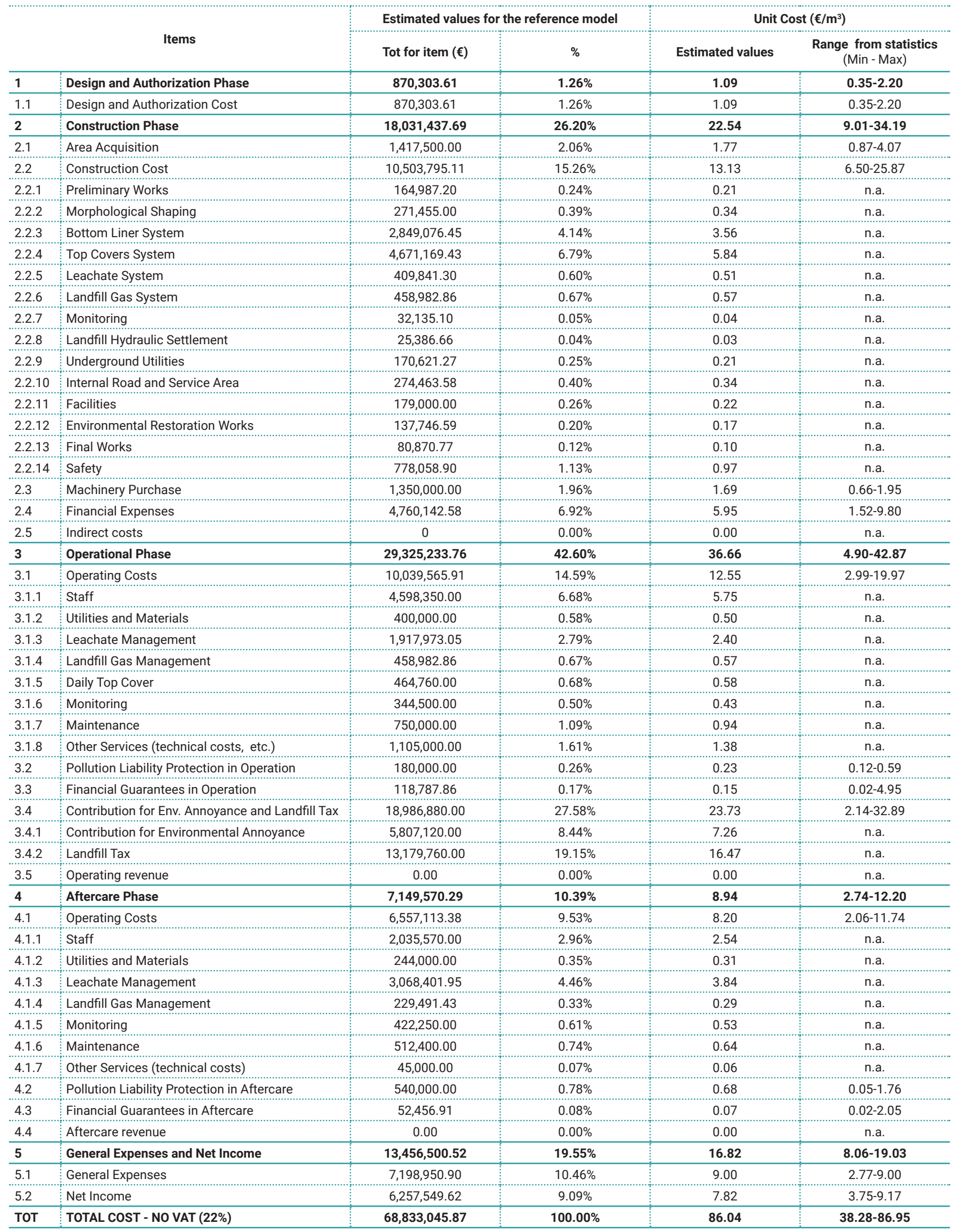

n.a.: not applicable or not available 
for meteorological data measurements and plates for settlements and diffused LFG monitoring.

Landfill hydraulic settlement refers to works necessary for the management of rainwater falling on the landfill surface: the perimeter channel all around the landfill and the rainwater drainage trench.

The cost of underground utilities grouped all the following systems: service area rainwater drainage system, first rainwater treatment system, water storage tank, wastewater system, service area drainage trench, electric network.

Internal road and service area cost is simply the cost due to the realization of the earth made road all around landfill perimeter and the asphalt for the service areas.

The costs for the office building, temporary storage basin, platform scale, and tire-washing system are all considered in facilities.

Environmental restoration works is the cost for landfill cover grass.

Final works include the cost for the fence, to prevent the uncontrolled access to people and animals; the gate, to permit the access for cars and trucks; and the area surrounding hedge, to hide the construction site.

Finally, safety cost contributes to the estimation of the construction cost and it represents approximately $8 \%$ of the cost due to all the other categories of this paragraph.

\subsubsection{Machinery purchase}

The investments for acquisition of new machinery includes: 1 tracked digger ( $€ 210,000.00$ ); 2 tracked operating machines for waste placement ( $2 \times € 250,000.00) ; 1$ agricultural tractor with brush-cutter arm (€ 160,000.00); $n^{\circ} 1$ compactor ( $€ 480,000.00$ ). This cost is extremely variable and has to be estimated on a case by case basis.

\subsubsection{Financial expenses due to investments}

The financial expenses associated with the investments (area acquisition, construction costs, machinery purchase) are calculated assuming full debt financing at an yearly interest of $6 \%$ (range 5-7\%) (Hogg, 2001; Florio, 2003) for a period of 10 years, equal to the duration of the operational phase. Constant rate amortization (Followill, 1998) was used for calculations, considering compounded interest.

\subsubsection{Indirect costs}

Indirect costs are difficult to quantify but they can potentially have a decisive role on the economic feasibility of the landfill.

An important indirect cost is the devaluation of the areas closed to the landfill. Devaluation of surrounding areas can reduce their original value $\left(5.00 € / \mathrm{m}^{2}\right)$ by more than $50 \%$ compared to before landfill construction. In addition, the effects of devaluation can extend for hundreds of meters (even a kilometre) from the landfill site, even in the case of well-designed and managed landfills.

In this case, considering the landfill model, some rough calculations can be made. Assuming an average value of the areas of $50,000.00 € /$ ha (before landfill construction) and considering $1 \mathrm{~km}$ radius of influence area, for a total of about 438 ha as the average depreciation (hypothesis that devaluation has linear behaviour, from $50 \%$ of pre-landfill value in the nearness of the landfill to $0 \%$ at $1 \mathrm{~km}$ of distance) can be estimated as follows:

\section{8 ha $\times 50,000 € /$ ha $\times 25 \%=5,475,000 €$}

which correspond to $6.8 € / \mathrm{m}^{3}$ in relation to the assumed landfill waste volume $\left(800,000 \mathrm{~m}^{3}\right)$. It is important to note how much depreciation can increase in the case of valuable surrounding areas and therefore its incidence on landfill cost.

In order to minimize local devaluation, some general criteria should be followed when choosing the landfill site. These criteria may include a distance from housing greater than $1 \mathrm{~km}$, preference of uncultivated or low-value areas, choice of a site with low visibility from urban centres, and from important landscape attractions and with easy and direct access from primary roads. On the contrary, the devaluation is near to zero in the case of environmentally degraded areas or previous landfill sites. However, in general, these costs are not mentioned in financial plans and they can be included in the cost for the area acquisition or into the contribution for landfill annoyance, as was done in the present study.

\subsection{Operational phase}

The economic analysis for the operational phase includes several different categories: operating costs, pollution liability protection, financial guarantees, contribution for landfill annoyance, landfill tax and landfill operating revenues.

In particular, pollution liability protection and financial guarantees are necessary to insure the site management to the benefit of the public administration in case of pollution, or rather in the case of bankruptcy/transfer of ownership of the company. Financial guarantees are also required for the aftercare phase.

On the contrary, the contribution for landfill annoyance and landfill tax are related only to the operational phase, in fact they have to be paid during the period of waste delivery.

\subsubsection{Operating costs}

The operating costs are the costs related to staff, utilities and materials, leachate and LFG management, daily top cover, monitoring, maintenance and other services.

Staff

The staff cost due to each job position can be obtained from the national tables FISE (2016) of recognition time for every single task and level, constituting a substantial part of the national contracts for environmental professionals. Considering 6 to 8 daily working hours and 250 working days/year, the staff cost according to task and responsibility is the following: $\mathrm{n}^{\circ} 1$ operation director (75 €/hour $x 2,000$ hours/year); $n^{\circ} 1$ technician responsible of the plant $(40.25$ $€ /$ hour x 2,000 hours/year); $n^{\circ} 2$ technical-administrative employees ( $2 \times 28.65 €$ /hour x 1,500 hours/year); 3 workmen ( $3 \times 23.53 € /$ hour $\times 1,500$ hours/year); $n^{\circ} 1$ supervisor (25.00 €/hour $\times 1,500$ hours/year). 


\section{Utilities and materials}

Utilities and materials include the cost of electricity, telecommunications, water, fuels, lubricants, reagents, and other consumables. In particular, the costs of electricity used by leachate pumps and LFG stations are not included because they are counted respectively under leachate management and LFG management. The yearly I cost has been set equal to $40,000.00 € /$ year.

\section{Leachate management}

Leachate management includes the costs related to utilities and to maintenance of the leachate system and the leachate treatment and/or disposal.

The leachate system cost is due to the electricity consumed by the pumps, while the cost for maintenance is calculated as $5 \%$ of the cost of leachate system construction.

Financial plans calculate this cost defining a unit price in reference to the volume of leachate produced, including transport and treatment; the cost can vary according to the leachate quality from $17 € / \mathrm{m}^{3}$ to $45 € / \mathrm{m}^{3}$, respectively for contaminated rainwater and for highly contaminated leachate (chemical oxygen demand (COD) > 10,000 mg/L). In this study a unit price of $40 € / \mathrm{m}^{3}$ has been considered for leachate disposal and, therefore, during the operational phase the total cost is: $40.00 € / \mathrm{m}^{3} \times 42,540.31 \mathrm{~m}^{3}=€$ $1,701,612$.

\section{Landfill gas management}

Unlike leachate management, the cost for LFG management is just due to LFG system utilities (mainly electricity consumed by the regulation stations, the extraction station and the flare) and maintenance. In fact, its disposal is not necessary because LFG is treated on site by combustion into a high temperature flare. These two contributions are both obtained considering $5 \%$ of the cost for LFG system construction.

\section{Daily top cover}

Differently from temporary and final top covers, daily top cover is strictly linked with the operational phase: it is placed every day on top of the waste disposed during that day. For this reason, it has been considered in this phase and not in the construction phase, as was the case for the temporary and the final top covers.

\section{Monitoring}

The monitoring activity follows the indications of the supervision and control procedure prescribed by D.Lgs. $36 / 03$. These activites have to be carried out by qualified and independent staff on: groundwater, leachate, drainage surface water, LFG, air, meteorological data, and landfill topography.

Groundwater controls for both volume and composition are required. Groundwater level is measured monthly in five piezometers with an average unit price of $25.00 € /$ measurement. For groundwater chemical analyses, the parameters are analyzed with the following frequency: quarterly for 11 parameters $(\mathrm{pH}$, temperature, electric conductivity, Kübel oxidability, chlorides, sulphates, Fe, Mn, ammonia nitrogen, nitrate, nitrite) and yearly for 26 parameters (fiveday biochemical oxygen demand (BOD5), total organic car- bon (TOC), $\mathrm{Ca}, \mathrm{Na}, \mathrm{K}$, fluorides, polycyclic aromatic hydrocarbons (PAH), heavy metals, cyanides, organic halogen compounds, phenols, pesticides and organic solvents). An average unit price of $20.00 € /$ parameter can be assumed.

Additionally, for leachate controls both volume and composition are required. Leachate level (indirect measure of the leachate volume) is measured monthly at the bottom of four lifting shafts with an average unit price of $25.00 € /$ measurement. For leachate chemical analyses, the samples are taken from the leachate storage tanks in order to obtain an average characterization of leachate extracted by the landfill. Parameters, frequency, and average cost are the same assumed for groundwater, except for BOD5, which is monitored quarterly. Moreover, the analysis of COD is also performed with quarterly frequency.

Chemical analyses on drainage surface water are performed on samples from four representative points, considering the same parameters and frequency assumed for leachate chemical analysis. The unit price considered is the same.

LFG quality analyses on $\mathrm{CH}_{4}, \mathrm{CO}_{2}, \mathrm{O}_{2}, \mathrm{H}_{2}, \mathrm{H}_{2} \mathrm{~S}$, total particulate matter, $\mathrm{NH}_{3}$, mercaptans, and volatile compounds are performed monthly at the extraction station (150.00 €/ measurement). The analysis for the assessment of biogas uncontrolled emission from the landfill surface are performed three times a year (1,500.00 €/campaign survey).

Air quality monitoring is made monthly by portable equipment in four points with an average unit price of $150.00 € /$ measurement; the analyzed parameters should be the same considered for LFG monitoring.

Meteorological data monitoring is conducted automatically by the weather station, where the following meteorological sensors are installed: rain gauge (for precipitation), air thermometer (for temperature), anemometer (for wind direction and velocity), evaporimeter (for the evaporation), air hygrometer (for the humidity). The minimum frequency of monitoring is daily for all the parameters for a total cost of $50.00 €$ /year.

Landfill morphology monitoring is performed through topographical surveys conducted twice a year for a cost of: $350.00 € /$ ha $\times 5$ ha $=1,750.00 € /$ each.

\section{Maintenance}

The maintenance cost includes the maintenance of machinery, facilities (such as the platform scale and tire washing system), underground utilities, and stations and systems for monitoring. Leachate and LFG system maintenance is not considered in this category because they are included in the leachate management and LFG management costs. The yearly cost for maintenance costs amounts to $75,000.00 € /$ year.

\section{Other services}

Other costs necessary during the operational phase are: technical costs for supervision and control procedure $(1,500.00 € /$ year); disinfection and disinfestation $(4,000.00$ $€ /$ year); deratting and bird control (5,000.00 €/year); commercial costs $(50,000.00 € /$ year); administrative costs $(50,000.00 € /$ year $)$. 


\subsubsection{Pollution liability protection in operation}

The insurance in case of a landfill project is the pollution liability protection and it is defined as a function of volume of the landfill, typology of waste, and location (site vulnerability).

In case of a landfill for non-hazardous waste (including also MSW), not located in a zone of aquifer recharge, the maximum coverage is of $€ 1,500,000$ for each $200,000 \mathrm{~m}^{3}$ of landfill volume (DGRV n. 2721/14).

On the basis of a volume of $800,000 \mathrm{~m}^{3}$, the calculated maximum coverage is of $€ 1,500,000$ for 4 sectors of $200,000 \mathrm{~m}^{3}=6,000,000 € /$ year.

The total pollution liability protection cost in operation is calculated for the 10 years of landfill life assuming a percentage of $0.3 \%$ of the maximum coverage and the costs amounts to: $6,000,000 € /$ year $x(0.3 / 100)=18,000 € /$ year $x$ 10 years $=€ 180,000$.

This percentage is difficult to establish because it depends on financial solidity of the company, but also on the capital market and waste quality. It can vary between $0.1 \%$ and $0.33 \%$ of the maximum coverage.

It is important to underline that the financial guarantees can be reduced if the company has environmental certifications: by $50 \%$ in case of and Eco-Management and Audit Scheme (EMAS) registration, by $40 \%$ in case of certifications in accordance with UNI EN ISO 14001 and still by 50\% if the enterprises complies with both of the environmental management systems (DGRV n. 2721/14).

\subsubsection{Financial guarantees in operation}

To obtain the authorization for a landfill, some financial guarantees must be provided in accordance with art. 14 of D.Lgs. $36 / 03$.

In particular, a guarantee is required for the activation and the operational management of the landfill, including closure procedures, withheld for at least 2 years from the closure communication date.

These guarantees are calculated considering a percentage of $0.8 \%$ (range $0.7-2 \%$ ) of the total planned cost for:

- Activation and operation costs;

- Costs for closure procedures and final recomposition of the landfill, such as the realization of the top covers, the construction of the 'embric' channels to drain the fallen rainwater on the closed landfill, and the landfill cover grassing.

In the case of landfills for which the authorization is approved for sectors, a guarantee can be given for them.

\subsubsection{Contribution for landfill environmental annoyance and landfill tax}

\section{Contribution for landfill environmental annoyance}

The contribution for environmental annoyances is a function of the non-hazardous waste typology (Special Waste or MSW) admitted in the landfill, according to DGRV n. 1104/2013.

In particular, remembering that non-hazardous special waste represents $70 \%$ of the total waste mass of the landfill model and the remaining $30 \%$ is MSW, the contributions for environmental annoyance are as follows:
- $(70 / 100) \times 880,000 t=616,000 t \times 5.00 € / t=€ 3,080,000$ for non-hazardous special waste;

- $(30 / 100) \times 880,000 \mathrm{t}=264,000 \mathrm{t} \times 10.33 € / \mathrm{t}=€$ $2,727,120$ for MSW.

\section{Landfill tax}

The landfill tax (called ecotax) is a form of tax required by art.3 of Italian Law n. 549/1995 in order to promote a lower waste production and the recovery of raw materials and energy from them. This tax is paid to the regional governments and is used to create a fund for inspection programs and long-term mitigation of environmental impacts related to disposal. It is applied on top of the other costs of the landfill causing a rise in the landfill gate fee. In this sense, it represents an inhibition of the disposal in comparison to preferable alternatives (Cossu and Masi, 2013). The amount of the tax is a function of the waste typology disposal in the landfill and established on a regional basis. In particular, according to LR n. $3 / 2000$, remembering that non-hazardous special waste represents $70 \%$ of the total waste mass of the landfill model, and the remaining $30 \%$ is MSW, the contributions for landfill tax are the following:

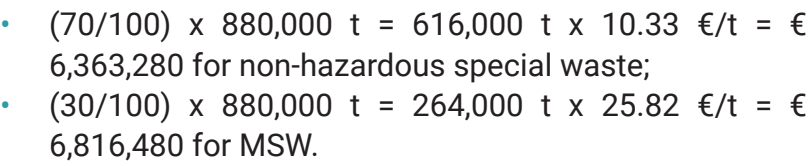

Biostabilized material used for daily and temporary/ final top covers, as the other materials used for landfill construction and management, are not subject to pay such contributions.

If municipalities reach a percentages of separate collection greater than $50-65 \%$ with respect the total collected waste, the landfill tax can be reduced by 35\% - 70\% (DGRV n. 288/2014). This discount is not considered in the present case study.

\subsubsection{Operating revenue}

The most common revenue from a landfill is generated by the sale of energy from LFG. In this case the price depends on the regime governing energy sales. The operators may contract out the management of LFG for energy recovery, and where energy prices are favourable, they may take a royalty fee in lieu of the contract.

In the case of plants which collect less than $100 \mathrm{~m}^{3} / \mathrm{h}$ of LFG (DGRV n. 995/2000), the energy recovery is not considered economically favourable because the product energy has to be treated which is an added cost. This is also the case for the present study. A separate category can be created for the revenue or it can be included in the mentioned economic categories.

\subsection{Aftercare phase}

The aftercare phase includes operating costs, pollution liability protection, financial guarantees and aftercare revenue. In particular, as for the operational phase, these costs represent non-negligible costs allocated to the total quantities deposited in the plant, even in case of plant stoppage. It is important to underline that these costs are collected when waste disposal starts, but they are saved and used 
after 30 years from the end of the operation activity. This fact introduces a serious management risk, because of the tendency to use these reserves to cover operational cash outflows, and because they can ultimately prove insufficient.

\subsubsection{Operating costs}

The operating costs during the aftercare phase are the costs related to staff, utilities and materials, leachate and LFG management, monitoring, maintenance, and other services.

During the 30 years of aftercare, costs are reduced to take into consideration the reduction of the required landfill activities.

\section{Staff}

The staff cost during the aftercare phase is obtained from the national tables FISE (2016) which were used for the operational phase. It includes: $n^{\circ} 1$ technician responsible of the plant (40.25 €/hour x 1,000 hours/year); $n^{\circ} 1$ workman (23.53 €/hour x 2,000 hours/year); ${ }^{\circ} 1$ responsible for supervision and control plan $(25.00 € /$ hour $\times 210$ hours/year).

These costs are reduced by about $30 \%$ every 10 years.

\section{Utilities and materials}

Utilities and materials include more or less the same costs of the operational phase, but the yearly consumptions are lower. As for the operational phase, these costs do not include the cost for electricity used by leachate pumps or biogas stations, which are accounted for in the leachate and LFG management categories.

Unlike the operational phase, the cost is not the same every year. This cost amounts to $€ 10,000$.00 for the first year, and then decreases about $20 \%$ every 10 years.

\section{Leachate management}

Leachate management during aftercare includes the same costs for the operation: consumptions and maintenance of the leachate system and leachate disposal. Differently from the operational phase, the amount of leachate does not vary each year, but it is assumed constant, so the leachate disposal cost amounts to: $40.00 € / \mathrm{m}^{3} \times 2,027.54$ $\mathrm{m}^{3} /$ year $=81,101.60 € /$ year, for a total of $€ 2,433,048$ in 30 years.

\section{Landfill gas management}

As for the operational phase, the cost for LFG management is just due to LFG system consumptions and maintenance. These two contributions are both obtained considering the $5 \%$ of the cost for LFG system construction for the first 5 years of the aftercare.

\section{Monitoring}

As for the operational phase, the monitoring follows the directions of the supervision and control procedures according to D. Lgs. 36/03, point 5 . The monitored matrices (the parameters and the points) are the same as the operational phase, but the frequency changes. The unit prices for the monitoring activity are assumed to not vary with time.

The groundwater level is measured twice a year where- as the quality composition is monitored half-yearly for the 11 fundamental parameters and yearly for the other 26 . The frequencies are the same respectively for the leachate level, fundamental parameters (13 in case of leachate), and the other parameters (25 in case of leachate). Chemical analyses on the drainage rain water are performed considering the same parameters and frequency for the leachate chemical analyses. For LFG, the quality analyses are conducted every six months for the extraction station and yearly (for the first 5 years) for the top covers to analyze the uncontrolled emissions. Air quality monitoring is conducted twice a year using portable unit at four points. The frequency of meteorological data monitoring can be reduced and the monitoring of wind direction and velocity is no longer required. Landfill morphology monitoring is performed through topographical surveys every six months for the first three years after that this monitoring is conducted yearly.

\section{Maintenance}

The maintenance cost during aftercare includes maintenance of underground utilities and of monitoring stations and systems, and maintenance of vegetative landfill covers and the restoration of depressions and caves. Consequently, the cost per year is lower than during the operational phase.

As for the operational phase, the leachate system and LFG system maintenance are not considered in this category, because they are considered respectively in the leachate management and LFG management costs.

These aspects amount to $€ 21,000.00$ for the first year, and then decreases about $20 \%$ every 10 years over the aftercare period.

\section{Other services}

Different from the operational phase, the only other services necessary in the aftercare phase are the technical costs which amount to $1,500.00 € /$ year.

\subsubsection{Pollution liability protection in aftercare}

The total pollution liability protection cost in aftercare is calculated for 30 years assuming a percentage of $0.3 \%$ of the maximum coverage estimated according to DGRV $n$. $2721 / 14$ as for the operational phase.

This cost amounts to: $6,000,000 € /$ year $\times(0.3 / 100)=$ $18,000 € /$ year $\times 30$ years $=€ 540,000$.

\subsubsection{Financial guarantees in aftercare}

Financial guarantees in accordance with D. Lgs. $36 / 2003$ include the costs for aftercare management of the landfill, and they are withholding for at least 30 years from the closure communication date.

These guarantees are calculated, as for the operational phase, considering a percentage of $0.8 \%$ of the planned aftercare cost without a value-added tax (VAT).

It is important to underline that for aftercare the guarantees are withheld for at least 30 years, which is a very long period in the financial market which could give rise to solvency issues. A valid solution to these problems could be a five-year automatic renewal period. 


\subsubsection{Aftercare revenue}

Energy production from LFG can represent an important revenue opportunity, especially if the activity was profitable during the operational phase. However, decreasing LFG production makes this option usually not convenient.

Other revenue possibilities can derive from innovative technical interventions on the surface of the final landfill top cover and their practical feasibility and economic convenience must be assessed on case by case basis. The installation of photovoltaic parks represent an already important and widely adopted solution. Furthermore, new opportunities are always considered and under development. This is the case of energy crops, which represent a promising opportunity for the near future. In the present study these aspects are not considered in the operational phase.

\subsection{General expenses and net income}

The general expenses and the net income have to be considered in order to define the landfill gate fee. The first corresponds to the $13 \%$ (range $13 \%-17 \%$ ) of the all costs calculated without VAT, the second to $10 \%$ of all costs plus general expenses (art. 32 of the DPR n. 207/2010).

\section{DISCUSSION}

Results obtained from the cost analysis of the whole life cycle of the landfill model are shown in Table 1. The unit cost is obtained by dividing the total cost by the waste volume: $€ 68,833,045 / 800,000 \mathrm{~m}^{3}=86.04 € / \mathrm{m}^{3}$. It represents the landfill gate fee, expressed per volume unit $\left(€ / \mathrm{m}^{3}\right)$ and is the sum of the costs related to design and authorization phase, construction phase, operational phase, aftercare phase, general expenses, and net income. None of these costs in the VAT.

The same calculation is repeated for all the three categories reported in Table 1, to obtain a unit cost for each category.

Economic categories level one and two have been compared with ranges obtained from the mentioned statistics, while this was not possible for level three because the investigated document used a different economic structure. It is worth mentioning that all unit costs fall into ranges, therefore it is reasonable to confirm that the goal to define a representative landfill case was achieved.

Regarding the cost distribution in the different landfill phases, the operational phase is where most of the costs are incurred (42.60\% of the total landfill cost); it is followed by the construction phase $(26.20 \%)$, the aftercare phase (10.39\%), and the design and authorization phase (1.26\%). Moreover, the last two phases together are referred to as lower costs relative to the general expenses and net income category (19.55\%).

Concerning financial expenses, the obtained wide range could be attributed to different assumptions. In some financial plans they are calculated based only on the construction cost (minimum value), while others consider the technical expenses as investment costs (maximum value). Among investment costs there are the construction costs, the area acquisition, and machinery purchases. Concerning area acquisition, this cost is difficult to generalize because it depends on many variables (position, presence of building, etc.). Concerning the machinery purchase, the estimated unit costs are quite high because all machinery is estimated to be bought as new items. Buying used machinery or renting can reduce these costs. Within the construction costs, the sub-category with the highest cost (15.26\%) also has a wide range which is a result of the different technical solutions and services adopted and strictly correlates to its geographical position (presence or not of an exhausted borrow pit, rather than mountainous or flat terrain) and to the quantity and quality of the disposed waste.

On the contrary, some of the sub-categories of the construction costs are set by the legislation which establishes many of minimum requirements for landfill construction in order to reduce environmental impacts. In this sense the model landfill was designed in accordance with the laws and the best practices and for this reason the corresponding percentages and unit costs align with the regulatory expectations.

For instance, top covers have the highest impact on construction costs followed by the bottom liner. Since the minimum thickness is fixed by the law, the cost may increase considering large landfill surfaces. In this view, an important cost minimization is obtained considering that the average height of the landfill should be greater than $1 / 10$ of its shorter base. This is usually obtained by designing landfills with a total landfill height of about 20-30 meters, like those realized in exhausted borrow pits, which is also the case of the present case study.

Operating costs in the operation and in aftercare phases both consist of staff time. In particular, the staff costs in the operational phase is higher than the costs in the aftercare phase, even if the aftercare period is three times the operation period (30 years versus 10 years). This trend is due to the fact that the operational phase requires more employers than the aftercare phase.

In the operational phase, which is the most expensive one, the definition of the operation time (statistically between 6 and 13 years) is fundamental because cost amounts are very sensitive to changes in the phase duration. Landfilling must therefore be planned carefully, avoiding operation stops, especially long ones. A stop in operations for one year may be onerous and bring important budget deficit challenges.

A further evaluation was carried out in order to identify the most important detailed costs. The analysis compares all of the single voices, not directly highlighted in Table 1 , used in the bill of quantities and in the financial panel. These results are reported in Figure 4 where two classes of costs are distinguished. The latter is related to environmental compensations and taxes that does not represent "real" operations where the technology can be applied and they can differ significantly from region to region and from regulation to regulation. In the present analysis these aspects constitutes above more than $1 / 4$ of the total costs. The latter is related to construction and management operations/ 
works and the results show that the most " 10 " relevant costs are correlated to leachate disposal (both in operational and aftercare phases), to staff (also in both phases), and to raw materials for liner construction.

Figure 5 represents the tornado chart for the sensitivity analysis of the most relevant costs. The $x$-axis represents the values of the total unit cost $\left(€ / \mathrm{m}^{3}\right)$ for different values of the independent unit prices. Each bar represents the range of values produced when each independent variable (unit price) is set to the lower bound, central value, and upper bound (with the other variables being held constant). In the present work, the central value is represented by the mean value of the unit price used directly in the model, while the lower and upper bounds were defined equal to $-20 \%$ and $+20 \%$ of the central value.

The dark grey indicates that the value is produced by the lower bound, while the light grey bar indicates that the value is produced by the upper bound (high). The vertical line between the two bars represents the mean value of $86.04 € / \mathrm{m}^{3}$. This analysis shows that a variation of $\forall \nabla 20 \%$ of the most significant unit prices determines a variation lower than $2 €$ of the total unit cost.

With a reduction of $50 \%$ of the landfill tax for MSW (the most sensitive unit price as reported in Figure 5) that can occur if a separate collection greater than $50-60 \%$ is reached, the total unit cost is reduced to $73.83 \mathrm{Euro} / \mathrm{m}^{3}$, saving 12.21 Euro per cubic meter of MSW waste landfilled.

In conclusion, the obtained unit costs have been compared to the values of the landfill gate fee for other Ital- ian Regions expressed as a function of the waste weight (Andretta et al., 2010). The average value of the unit cost of Figure 6 is $84.96 € / t$ relative to $78.22 € / t$ (density $=1.1 \mathrm{t} / \mathrm{m}^{3}$ ) obtained from the model landfill. This fact points out that the correct average behaviour assumption for the model landfill was reasonable and was also supported by the unit cost point of view.

\section{CONCLUSIONS AND FURTHER DEVELOP- MENTS}

Landfill costs were defined for a model landfill representative of Northern Italy that refers to the whole landfill life, including the phases of design and authorization, construction, operation, and aftercare. Results were expressed per unit of landfill volume available for waste and compared with economic values obtained from a statistical analysis of several landfill cases and from literature values of different Italian regions. The obtained landfill fee gate (86.04 $\left.€ / m^{3}\right)$ is in line with the analysed references and depends mainly on the costs of the landfill tax, the contribution from landfill environmental annoyances, the leachate disposal fees, the staff, and raw materials for liner construction. However, other factors can significantly influence the landfill gate fee: location (presence or not of an exhausted borrow pit, rather than mountainous or flat terrain; presence of building, roads, network services, etc.), climatic conditions (mainly for leachate production), waste quality for LFG and leachate production, landfill geometry (in particular the

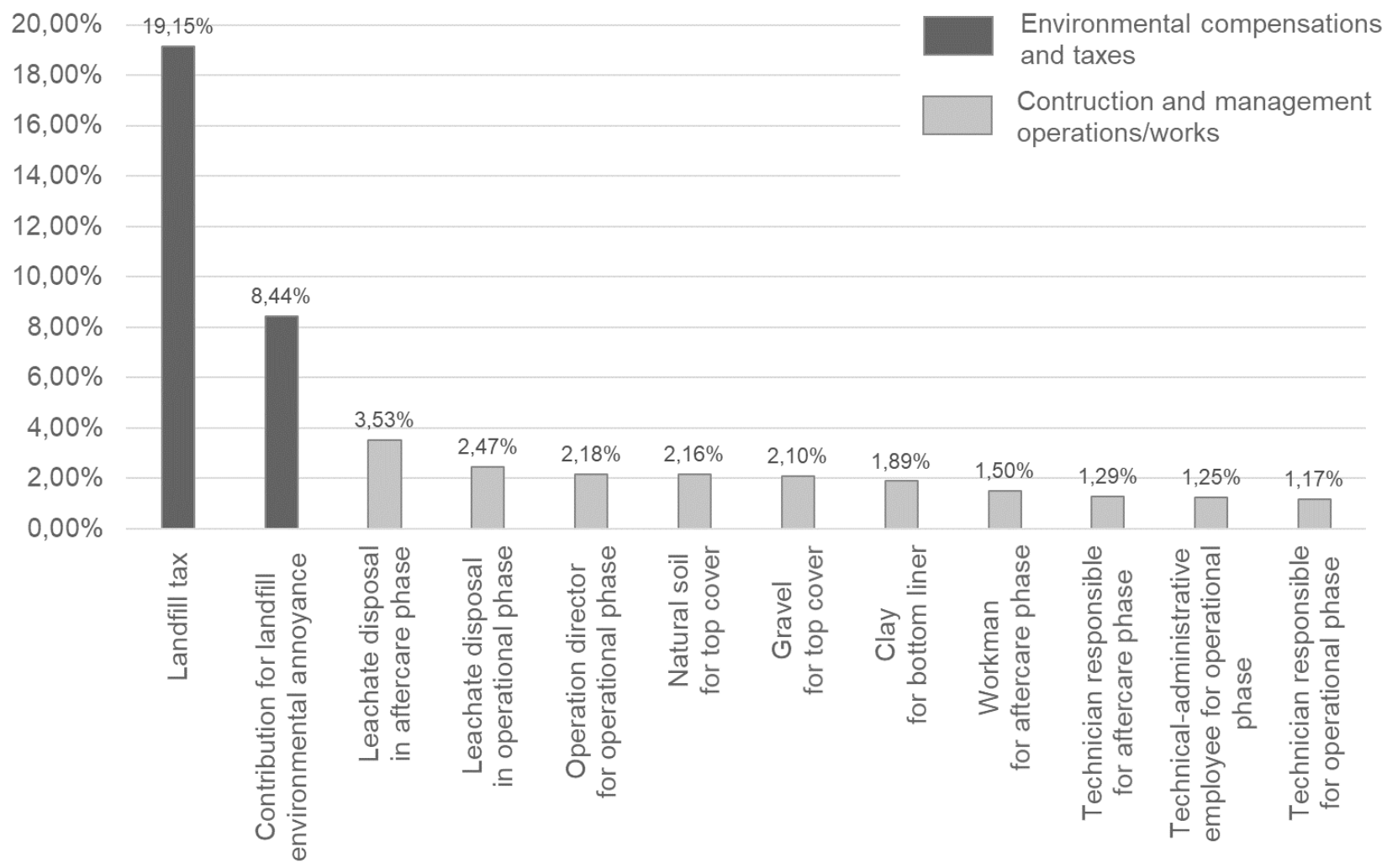

FIGURE 4: Top detailed economic voices for the definition of landfill gate fee or the reference landfill model. Two classes of costs were considered: environmental compensation and taxes and construction and management operation/works. 


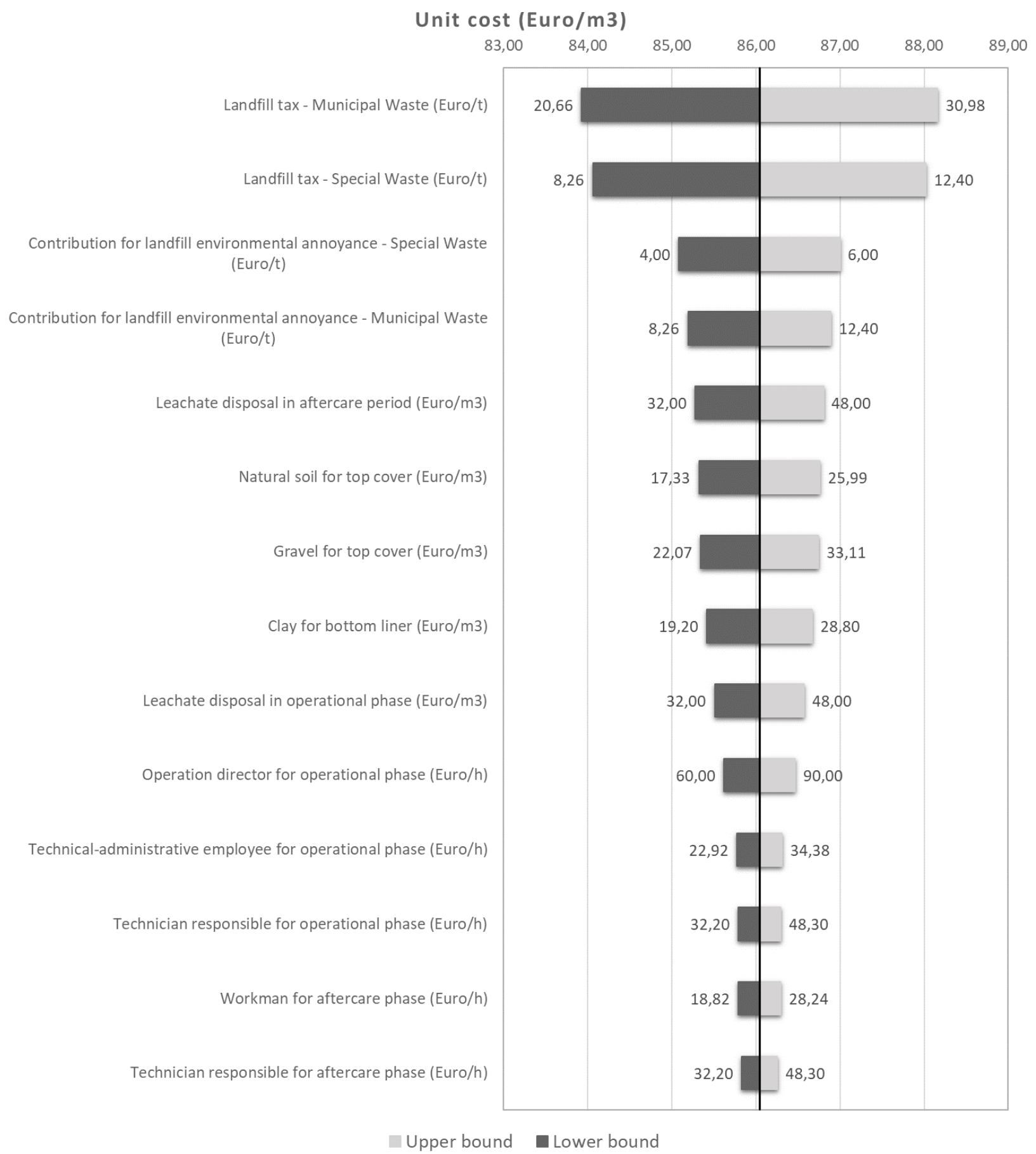

FIGURE 5: Tornado chart for the sensitivity analysis of the most significant unit prices.

ratio surface/height of waste), operative procedures (daily cover, utilization factor of the volumes, etc.), financial aspects (area acquisition, interest rate for the investments, financial guarantees, etc.) and legal aspects (pollution liability, contribution for environmental annoyance and landfill tax).

This study can be used as a starting point for a comparative economic analysis. For instance, the assumed model landfill can represent a reference scenario useful for the comparison of different landfill configurations (size, operational time, biogas recovery, etc.) and for the assessment of new innovative technology applications, such as energy crop application, in-situ aeration, and flushing.

\section{ACKNOWLEDGEMENTS}

This work was possible thanks to the effort and the co-operation of the technicians: Giuliano Marella (Department of Civil, Environmental and Architectural Engineering, University of Padova, Italy); Roberto Brunetta (ASI Insurance Brokers srl) and Marco Moretto. The Authors would like to thank Stefano Merli who accurately revised the work. 


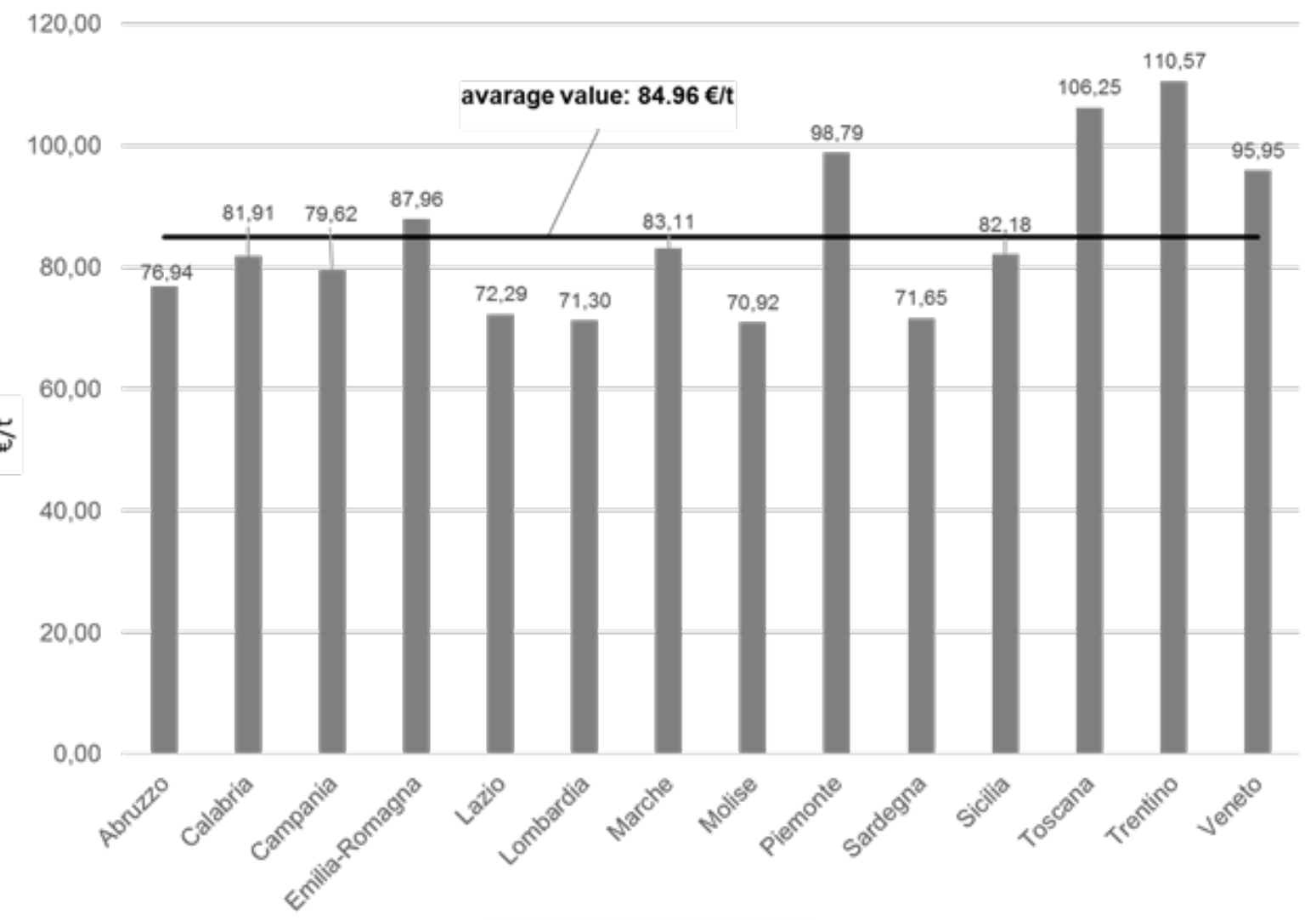

Italian Regions

FIGURE 6: Average values for landfill gate fee in other Italian Regions.

\section{REFERENCES}

Andretta, A., Montresori, G., Sunseri, M., 2010. Le tariffe di trattamento e di smaltimento dei rifiuti urbani in Italia, in: Atzori, A., Baroni, P., Levorato, A., Moretto, A., 2010. La regolazione e il controllo dei servizi di gestione dei rifiuti urbani, buone pratiche di regolazione locale. FrancoAngeli, Milano, pp. 200-234. (In Italian)

Blakey, N. C., 1992. Model prediction of landfill leachate production, in: Christensen, T. H., Cossu, R., Stegmann, R., 1992. Landfilling Waste: Leachate. E \& FN SPON, London, London, pp. 17-34.

Canziani, R., Cossu, R., 1989. Landfill hydrology and leachate production, in: Christensen, T. H., Cossu, R., Stegmann, R., 1989. Sanitary Landfilling: Process, Technology and Environmental Impact. Academic Press, London, pp. 185-212.

CNI (Consiglio Nazionale Ingegneri), 2016. Monitoraggio sui bandi di progettazione $3^{\circ}$ trimestre 2016 terzo trimestre consecutivo in crescita per le gare per l'affidamento di servizi di architettura e ingegneria in Italia. www.centrostudicni.it (accessed 28/01/2017).

Cossu, R., Andreottola, G., Muntoni, A., 1992. Modelling landfill gas production, in: Christensen, T. H., Cossu, R., Stegmann, R., 1989. Landfilling of Waste: Biogas, E \& FN SPON, London, 1996, pp. 237-268.

Cossu, R., Masi, S., 2013. Re-thinking incentives and penalties: Economic aspects of waste management in Italy. Waste Management. Vol 33, pp. 2541-2547.

Council Directive 1999/31/EC of 26 April 1999 on the landfill of waste.

CTD, 1997. Linee guida per le discariche controllate di rifiuti solidi urbani. Cisa Publisher. (In Italian)

Decreto legislativo 13 gennaio 2003, n. 36 (D. Lgs. 36/2003). Attuazione della direttiva 1999/31/CE relativa alle discariche di rifiuti. (In Italian).

Decreto legislativo 3 aprile 2006, n. 152 (D. Lgs. 152/2006). Norme in materia ambientale. (In Italian).

Decreto ministeriale 31 ottobre 2013, n. 143 (DM 143/2013). Regolamento recante determinazione dei corrispettivi da porre a base di gara nelle procedure di affidamento di contratti pubblici dei servizi relativi all'architettura ed all'ingegneria. G.U. n. 298 del 20 dicembre 2013. (In Italian).
Deliberazione della Giunta Regionale Lombardia n. X/2461 del 7 ottobre 2014 (DGR n. X/2461/2014). Linee guida per la progettazione e gestione sostenibile delle discariche. (In Italian).

Deliberazione della Giunta Regionale Veneto n. 1104 del 28 giugno 2013 (DGRV n. 1104/2013). "Articolo 37 della legge regionale 21 gennaio 2000 , n. 3 come modificato dall'art. 41 della legge regionale 6 aprile 2012 , n. 13. Prima individuazione dell'entità del contributo da applicare in via sperimentale quale compensazione economica al disagio dovuto dalla presenza di impianti di gestione dei rifiuti. DGR $\mathrm{n}$. 12/CR del 29/01/2013." Revoca e sostituzione. (In Italian).

Deliberazione della Giunta Regionale Veneto n. 1245 del 01 agosto 2016 (DGRV n. 1245/2016). "Programma regionale per la riduzione dei rifiuti biodegradabili da avviare in discarica" - Aggiornamento relativo allo stato di attuazione - Annualità 2014. (In Italian).

Deliberazione della Giunta Regionale Veneto n. 2721 del 29 dicembre 2014 (DGRV n. 2721/2014). Approvazione schema di "Garanzie finanziarie a copertura dell'attività di smaltimento e recupero di rifiuti". D.Lgs.n. 152/2006 e s.m.i. ed integrazione delle disposizioni regionali vigenti in materia. (In Italian).

Deliberazione della Giunta Regionale Veneto n. 288 del 11 marzo 2014 (DGRV n. 288/2014). "Pagamento del tributo speciale per il conferimento in discarica in misura ridotta per le Amministrazioni comunali che raggiungono precisi obiettivi di raccolta differenziata ai sensi dell'art. 39, commi 4 e 4-bis, della L. R. 3/2000. Nuova procedura e metodo di calcolo per la certificazione annuale della percentuale di raccolta differenziata ai fini ecotassa secondo le modifiche introdotte dall'art. 44, L.R. 5.04.2013 n. 3. DGR n. 162/ CR del 10 dicembre 2013." (In Italian).

Deliberazione della Giunta Regionale Veneto n. 995 del 21 marzo 2000 (DGRV n. 995/2000). "Specifiche tecniche e sussidi operativi alla elaborazione degli Studi di Impatto Ambientale per gli impianti di trattamento e smaltimento rifiuti. (In Italian).

Decreto del Presidente della Repubblica n. 207 del 5 ottobre 2010 (DPR n. 207/2010). "Regolamento di esecuzione ed attuazione del decreto legislativo 12 aprile 2006, n. 163, recante «Codice dei contratti pubblici relativi a lavori, servizi e forniture»". (In Italian) 
Directive 2008/98/EC of the European parliament and of the Council of 19 November 2008 on waste and repealing certain Directives.

FISE (Federazione Imprese di Servizi), 2016. http://www.fise.org/index. $\mathrm{php/fise/associazioni/assoambiente} \mathrm{(accessed} \mathrm{28/01/2017).} \mathrm{(In}$ Italian)

Florio, M., 2003. Guida all'analisi costi benefici dei progetti di investimento. Linee Guida per Unità di Valutazione, DG Politica Regionale e Coesione, Commissione Europea. (In Italian)

Followill, R., 1998. An analytical comparison of the durations and price sensitivities of fixed-rate, constant payment and constant amortization mortgages. In International Review of Financial Analysis, Volume 7, Issue 1, 1998, Pages 51-64.

Garbo, F., Lavagnolo,M.C. Malagoli, M., Schiavon, M., Cossu, R., 2017. Different leachate phytotreatment systems using sunflowers. Waste Management, 59, pp 267-275. DOI:10.1016/j.wasman.2016.10.035.

Hogg, D., 2001. Costs for Municipal Waste Management in the EU. Final Report to Directorate General Environment, European Commission, Brussels.

ISPRA (Istituto Superiore per la Protezione e la Ricerca Ambientale), 2012. Guida Tecnica per la progettazione e gestione dei sistemi di fitodepurazione per il trattamento delle acque reflue urbane. Manuali e Linee Guida 81/2012. (In Italian).

ISPRA (Istituto Superiore per la Protezione e la Ricerca Ambientale), 2016. Criteri tecnici per stabilire quando il trattamento non è necessario ai fini dello smaltimento dei rifiuti in discarica ai sensi dell'art. 48 della L. 28 dicembre 2015 n. 221. Manuali e Linee Guida 145/2016. (In Italian).

Laraia, R., 2017. Special waste in Europe and in Italy. Ecoscienza 16-19.

Kunreuther, H., Easterling, D., 1996. The Role of Compensation in Siting Hazardous Facilities. Journal of Policy Analysis and Management, Vol. 15, No. 4, pp. 601-622.
Lavagnolo, M.C., Malagoli, M., Garbo, F., Pivato, A., Cossu, R., 2016. Labscale phytotreatment of old landfill leachate using different energy crops. Waste Management, 55 pp 265-275. DOI: 10.1016/j.wasman.2016.06.016.

Legge 28 dicembre 1995, n.549, "Misure di razionalizzazione della finanza pubblica". (In Italian)

Legge Regionale del Veneto n. 3/2000 (LR n. 3/2000), "Nuove norme in materia di gestione dei rifiuti”. BUR n. 8/2000. (In Italian).

Lombardia Region Price List, 2011. Prezzario delle opere pubbliche della regione Lombardia, Tipografia del Genio Civile. (In Italian)

Pedemontana Veneta, 2011. Accordo sulle procedure e metodologie da adottare per la determinazione delle indennità di espropriazione per la realizzazione della superstrada a pedaggio Pedemontana Veneta. http://www.commissariopedemontana.it/commissariopedemontana/docs/accordo\%20procedure.pdf. (accessed 28/01/2017). (In Italian)

Pivato, A., Vanin, S., Palmeri, L., Barausse, A., Mangione, G., Rasera, M., Gianluca, M., 2013. Biopotentiality as an index of environmental compensation for composting plants. Waste Management, 33 (7), pp. 1607-1615. DOI:10.1016/j.wasman.2013.03.023.

Raga, R., Cossu, R., Heerenklage, J., Pivato, A., Ritzkowski, M., 2015. Landfill aeration for emission control before and during landfill mining. Waste Management, 46, pp. 420-429. DOI: 10.1016/j.wasman.2015.09.037.

Veneto Region Price List, 2013. http://www.regione.veneto.it/web/ lavori-pubblici/prezzario-regionale (accessed 28/01/2017). (In Italian)

Ziyang, L., Luochun, W., Nanwen. Z., Youcai, Z., 2015. Martial recycling from renewable landfill and associated risks: A review. Chemosphere Volume 131, pp 91-103. 